\title{
Kayırmacılık Algısının Örgütsel Muhalefet Davranışı Üzerindeki Etkisi ${ }^{1}$
}

\author{
(Araştırma Makalesi)
}

The Effect of Nepotism Perception on Organizational Opposition Behavior

Doi: 10.29023/alanyaakademik.688172

Ahmet YILDIRIM

Dr. Ögrr. Üyesi, Süleyman Demirel Üniversitesi, IIIBF, Insan Kaynakları Yönetimi

ahmet.yildirim@sdu.edu.tr

Orcid No: 0000-0002-1208-071X

\section{Aytekin TOKGÖZ}

aytekin.tokgoz@hotmail.com

Orcid No: 000-0002-9143-4626

Bu makaleye atıfta bulunmak için: Yıldırım, A. \& Tokgöz, A. (2020). Kayırmacılık Algısının Örgütsel Muhalefet Davranışı Üzerindeki Etkisi. Alanya Akademik Bakış, 4(3), Sayfa No.541-560.

\section{ÖZET}

Anahtar kelimeler:

Örgütsel

Kayirmactlı,

Örgütsel Muhalefet

Makale Geliş Tarihi:

12.02.2020

Kabul Tarihi:

10.09.2020
Bu araştırma kayırmacılık (nepotizm) algısının, örgütsel muhalefet davranışı üzerinde oynadığ rolü tespit etmek amacıyla yapılmıştır. Araştırmanın evrenini bir kamu yerel yönetim örgütü olan Il Özel İdare Genel Sekreterliklerinde görev yapan çalışanlar oluşturmaktadır. Kolayda örnekleme yöntemi kullanilarak dijital ortamda gönderilen anket formlarından geri dönen ve incelemeye uygun 173 form incelemeye alınmıştır. Değişkenler arasındaki etkiyi tespit etmek üzere SPSS ve AMOS programlarından yararlanılmıştır. Araştırmada kullanılan değişkenlerin aralarındaki ilişkilerin ve etkilerin test edilmesinde korelasyon ve regresyon analizi kullanılmıştır. Kayırmacılı̆̆a ilişkin algıların örgütsel muhalefet davranışına pozitif yönde anlaml olarak yordadĭ̆l, kayırmacılı̆̆ın alt boyutlarına ilişkin terfi, işlem ve işe alma algılarının örgütsel muhalefet davranışının yaklaşık olarak yüzde 76'sını açıkladĭ̆ı tespit edilmiştir. Araştırma neticesi elde edilen bulgular alanyazın doğrultusunda tartışılmış ve farklı çalışmalar için önerilerde bulunulmuştur.

\footnotetext{
${ }^{1}$ Bu makale, Süleyman Demirel Üniversitesi Sosyal ve Beşeri Bilimler Etik Kurulu’nun 23.07.2020 tarihli ve 95/9 sayılı kararı ile fikri hukuki ve telif hakları bakımından etik olarak uygun bulunmuştur.
} 
Keywords:

Organizational

Nepotism,

Organizational

Opposition

\section{ABSTRACT}

This research was conducted to determine the role of nepotism perception in organizational opposition behavior. The universe of the research is the employees working in the Provincial Private Administration General Secretariat, a public local government organization. There were 173 forms returned from the questionnaire forms sent digitally using the easy sampling method and suitable for examination were included in the examination. SPSS and AMOS programs were used to determine the effect between the variables. Correlation and regression analysis were used to test the relationships and effects between the variables used in the research. It is seen that perceptions about nepotism, nepotism the sub-dimensions of nepotism, transaction and hiring perceptions about organizational opposition behavior, positively and significantly affect 76 percent of organizational opposition behavior. The findings of the research were discussed in line with the literature and suggestions were made for different studies.

\section{GİRIŞ}

Örgütler açısından yaygınlık içerdiği için dikkatle izlenmesi gereken bir kavram haline gelen kayırmacılık, özellikle kamu örgütleri açısından bir davranış türü haline gelmiştir ve çalışanları ve örgütün işleyişini doğrudan etkileyebilmektedir.

Tarihsel bağlamda birçok toplumda kayırmacılık uygulamalarının farklı biçimlerde uygulandığını gösteren bulgulara rastlanmakla beraber (Çarıkçı ve Arslan, 2010: 37), geleneksel toplum yapısında ve informal ilişkilerin yoğun olarak yaşandığı ve piyasa mekanizmasının yeterince gelişmemiş olduğu ülkelerde daha yaygın olarak görülmektedir (Özler vd., 2007).

Kavram temelde, çalışanların kazanılmış niteliklerini dikkate almadan, sosyolojik açıdan akrabalık ilişkilerine bağlı olarak istihdam edilmesi ya da bir makam/mevkiye atanması olarak tanımlanabilir.

Çalışan istihdamında kayırmacı ilişkilerin varlığı, hem çalışanlar hem de örgütler açısından olumsuz etkiler barındırmaktadır. Örgütlerin tanımlanmış nitelikleri taşımadan çalışan istihdam tercihi ya da terfi sistemi, çalışan algısı açısından olumsuz motivasyon sorunlarına sebebiyet vermektedir. Kayırmacılığa bağlı olarak işe alım, performans değerlendirme, ücretlendirme ve terfi süreçlerinde ciddi problemler ortaya çıkmaktadır.

Kayırmacılık neticesi örgütlerin etkinliği ve verimliliği düşmekte, örgüt içi olumlu örgüt ikliminin oluşmasını engellenmekte, kurumsallaşma merhalesi sekteye uğratmakta ve kurumsallaşmanın getirdiği avantajlardan yararlanılmasına engel olmaktadır.

Örgütler açısından insan unsurunun tartışılmaz önemi, insan kaynakları yönetimine yönelik ilginin artmasını sağlamıştır. Ancak çalışan istihdamında ya da terfiye dayalı kariyer yönetimine yönelik sistemli insan kaynakları uygulamalarına rağmen kayırmacı davranışların tercih edilmesi örgütlerin insan sermayesinin yönetilmesinde problemlere de kaynaklık etmektedir.

Örgütlerde istihdam ve terfi tercihinde kayırmacı uygulamalarının örgütsel muhalefet davranışları gösterme eğilimine etkisi bu araştırmanın problemini oluşturmaktadır. İşe alım 542 
veyahut terfi sürecinde yapılan kayırmacılık sonucunda yetenekli ve işe en uygun olan adayın yerine kayırılan kişinin tercih edilmesi, örgütün çıkarlarının göz ardı edilmesine ve örgüte olan güven duygusunun zedelenmesine sebebiyet vererek çalışanların eleştirel ve muhalif bir tavır içerisine girmesine neden olmaktadır.

Niteliklerinden ziyade, farklı kıstaslara bağlı olarak belli bireylere ayrıcalık verilmesi, diğer çalışanlar açısından rahatsız edici bir durumdur ve doğal olarak güven erozyonu, iş tatmini eksikliği, örgütsel sadakatin zayıflaması ve olumsuz bireysel performans ortaya çıkarmaktadır.

Alanyazında kayırmacılığın örgüt düzleminde olumlu etkilerine dair bazı çalışmalar mevcuttur. Ancak ağırlıklı olarak kayırmacılık çalışanların örgüte olan güven ve iş motivasyonlarını olumsuz yönde etkilemekte, eşitlik ve adalet algılarının bozulmalarına neden olmaktadır.

\section{KAVRAMSAL ÇERÇEVE}

\subsection{Nepotizm/Kayırmacılık}

Latince“de "yeğen" anlamına gelen "nepos" kelimesi köküne dayanan nepotizm (Kiechel, 1984:143) Rönesans döneminde papaların yeğenlerine prestijli bir iş bulmak için imtiyazlarını kullanmaları nedeniyle olumsuz bir anlama evrilmiştir.

Nepotizm/kayırmacılık terim olarak, "koruma, himmet iltimas" olarak, kayırmak, "koruyarak başarısını sağlamak, elinden tutmak, himmet etmek, birini başkalarının veya işin zararı pahasına tutmak, haksız yere kolaylıklar sağlamak, iltimas etmek" (TDK, 1998:1249) anlamlarına gelmektedir. Öte yandan "bir kişi veya zümre lehine hak ve adaletten sapma eğilimi" (Erdem, 2012), "bireyin aile bağlarını kullanarak hak etmediği bir işe yerleşmesi" (Ferlazzo ve Sdoia, 2012:1), "kişinin, işin gerektirdiği kabiliyet yetenek ve özelliklerine sahip olmadan sadece akrabalık bağlarını kullanarak istihdam edilmesi” (Jaskiewicz ve diğerleri, 2013:121), "örgüt üzerinde söz hakkı olanlarla ilişkilerine bakılarak, niteliksiz çalışanların işe alınması veya terfi ettirilmesi” (Bierman ve Fisher 1984: 634), "örgütte akrabaların istihdam edilmesi” (Karacaoğlu ve Yörük, 2012: 46), anlamlarında da kullanılmıştır.

Kayırmacılık alanyazında olgusal gerçekliği ile ilişkili boyutları ve türleri açısından sınırlandırılarak anlamlandırılmıştır. Kayırmacılığın akrabalık ilişkilerini kapsadığı türü olan davranışlar "nepotizm", kan bağı dışındaki eş-dost kayırmacılığı "kronizm", ideolojik ve siyasal nitelikli kayırmacılık "patronaj", iktidar seçkinliğine dayalı kayırmacılık ise "klientelizm" olarak değerlendirilmektedir (Aközer, 2003: 16-17).

Nepotizm ve Kronizm arasında vurguladığı olgu düzeyinde belirgin farklılıklar bulunmamakla birlikte, temel ayrışmanın Nepotizm'de akrabalık ilişkilerinin Kronizm de ise arkadaşılık, dostluk gibi yakın ilişkilerin ön planda olmasıdır.

Siyasal nitelikli kayırmacılık olan patronaj, siyasi partilerin iktidar olmaları ile beraber üst düzey pozisyondaki kişileri görevden alarak yerlerine akraba, arkadaş ilişkileri, hemşehricilik, siyasi yandaşlık gibi faktörler göz önünde bulundurularak atama yapmalarıdır (Özsemerci, 2003). Patronaj düzeyinde kayırmacılığın yaygın olduğu bir yönetim anlayışında, ilişkileri ön planda tutarak yönetimde yetki vermek; liyakat ilkelerine göre makam ve yetkinin verilemediği bir sistemin oluşmasına ve politikacıların sistemin işleyişini müdahalesine neden olmaktadır (Hamilton, 2010). Kamu hukuku kurallarının daha esnek 
olduğu toplumlarda mal ve hizmetlerin kişiler arasında tercihli olarak değişimi olarak tanımlanan Klientelizm, kamu kaynaklarının ilişkilere dayalı olarak yandaşlar arasında dağıtılmasıdır.

Kayırmacılık hem kamu örgütlerinde hem de özel sektör örgütlerinde karşılaşılan önemli sorunlardan biridir ve olumsuz bir içeriğe sahiptir (Asunakutlu, Avcı, 2010). Kayırmacılık "yozlaşma" olarak da ifade edilmekle birlikte bürokraside, iş yaşamında karşılaşılan önemli problemlerden biri olarak ortaya çıkmaktadır (Kayabaşı, 2005). İlhan ve Aytaç (2010)'da kayırmacılık türü davranışların ülkemizde yaygın olarak görüldüğünü, kişilerin birbirleriyle olan akrabalık bağı veya arkadaşlık, hemşerilik, ideolojik sebepler gibi çeşitli yakınlıklardan dolayı arka çıkma, kollama, koruma, destekleme gibi davranışlarının olağan karşılandığını ve sıradan bir tutum/davranış olarak görüldüğünü belirtmektedir.

Alanyazında kayırmacılık ile akrabalık, eş-dost ilişkileri ve politik nedenlerle kişilerin ödüllendirildiği, terfi ettirildiği ya da desteklendiği, işe yerleştirmede haksızlık yapıldığı, yasalara aykırı uygulamalarda bulunulduğu, adaletsiz uygulamaların söz konusu olduğu gibi konulara işaret edilmiştir. Ülkemizde sıklıkla karşılaşılan kayırmacılık davranışlarının türevleri işe alma ve işten çıkarmada; terfi ve performans değerlendirilmelerinde, ücretlendirme, çalışma saatlerinde esneklik, gibi işlem kayırmacılığı olarak karşımıza çıkmaktadır (Özüren, Paksoy, 2019).

Kayırmacılık, alanyazında terfide kayırmacılık, işlem kayırmacılığı, işe alma kayırmacılığı olmak üzere 3 boyutlu bir içerikle incelenmektedir (Ford and McLaughlin 1985; Abdalla vd. 1998; Asunakutlu ve Avc1 2009; Özüren ve Paksoy, 2019, Karahan, Y1lmaz, 2014).

Kayırmacılığın sıklıkla görüldüğü terfi işlemlerinde sübjektif kriterler öne çıkarılmakta terfi kararların da kişisel ilişkiler, akrabalık bağları gibi etmenler belirleyici olmaktadır. Çalışanların performanslarına, yetenek ve yeterliliklerine uygun bir şekilde terfi almalarını sağlamak örgütsel adalet ve örgütsel muhalefet algılarına olumlu düzeyde yansımaktadır. Alanyazında terfide kayırmacılığın, işe alma kayırmacılığ değişkenlerle ilişkisi daha yüksek düzeydedir (Kurt, Doğramacı, 2014). Terfi kayırmacılığ1 uzun vadede örgütlerin insan kaynakları politikaları açısından kurumsallaşmalarını sekteye uğratacak algıya da sebebiyet vermektedir.

Örgütlerin belirlenmiş hedeflerine ulaşabilmesinde sahip olduğu kaynaklarını verimli kullanması çok önemlidir. Dolayısıyla insan kaynağının nitelikli çalışanlarda oluşması önemli stratejik bir beklentidir. İnsan kaynağı işe alım sürecinde genellikle eğitim, iş deneyimi ve işle ilgili kişisel özellikler gibi ölçütler değerlendirilmektedir (Şimşek ve Öge, 2007: 192). Ancak işe alım süreçlerinde kayırmacılığın etkili olduğu görülmektedir. Alanyazında bazı çalışmalarda işe alma kararlarından yetkili kişilerin, genellikle eğitim, liyakat ve yetenek ölçütlerini dikkate almadan yalnızca akrabalık bağlarını gözeterek istihdam politikaları yürüttüklerini göstermektedir. Ancak, Ford ve McLaughline (1985, :59) kayırmacılığın işe alımlarda hak edenlerin değil de hak etmeyenlerin getirilmesinin diğer çalışanlar üzerinde olumsuz etkiye neden olduğunu düşünmektedir.

Kayırmacılığın bir diğer boyutu olan işlem kayırmacılı̆̆ı çalışanların bir kısmının işin niteliğine göre daha avantajlı işlerde çalıştırılması durumudur. Diğer bir ifade ile çalışanların yeterlilikleri aynı fakat işin zorluğu gibi nedenlere dayalı olarak bazı çalışanların kayırılması halidir. İşlem kayırmacılığı örgütsel muhalefet söylemlerine en fazla kaynaklık eden kayırmacılık türü olarak da nitelendirebiliriz.

544 
Yıldırım (2013) kamunun önemli sorunu olarak tanımladığı "kayırmacılık" olgusunu, işe alınmada ve terfide siyasi yönden taraf olma, memuriyet kadrolarının yandaş kişiler arasında dağıtılması ve particilik ilişkisiyle kadrolaşmanın yolu olarak kullanıldığına işaret etmiştir. Ülkemizde sıklıkla karşılaşılan bir kayırmacılık türü kamu görevlerinde, yönetimin kendine yakın hissettiği bazı kişileri haksız yere ve yasalara aykırı olarak desteklemesi, koruması ve kayırmasıdır. Bu anlamda kavram, "iltimas" kavramı ile eş anlamlı bir içeriğe evrilmiş ve halk arasında kullanılan "torpil” kavramına karşılık gelmektedir (Aktan, 2001:57)

Kayırmacılık; kamuda görev yapan bir görevlinin birlikte görev yaptığı bir çalışanı hukuki normların dışında koşulsuz bir şekilde desteklemesi ya da hak etmemesine rağmen, yeterliliklerine ve performansına bakılmaksızın terfi ettirilmesi, hak etmediği parayı kazanması olarak tarif edilebilir (Aydoğan, 2009:20).

İlgili alanyazında kayırmacılık kavramına ilişkin yapılmış araştırmalarda kayırmacılığın örgütleri ve çalışanları olumsuz yönde etkilediği tespit edilmiştir (Baldanova, 2014; Khatri ve Tsang, 2003; Pearce, 2015; Safina, 2014; Turan, 2015). Kayırmacılık olgusunun, iş doyumu, iş tatmini, özyeterlik, örgütsel adalet, örgütsel destek, örgütsel bağlılık, yenilik ve yetenek yönetimi kavramlarıyla ilişkisinin belirlendiği araştırmalar yapılmış ve çalışmalarda olumsuz yönde anlamlı ilişkinin varlığına rastlanılmıştır (Asunakutlu ve Avcı, 2010; Aydın, 2016; Demirel ve Savaş, 2017; Erdem, Ceylan ve Saylan, 2013; Geçer, 2015; Karacaoğlu ve Yörük, 2012; Turgut, 2014). Buna karşın, örgütsel sinizm, işten ayrılma niyeti ve olumsuz söz söyleme kavramlarıyla ilişkisinin incelendiği araştırmalarda pozitif yönlü anlamlı ilişki tespit edilmiş (Aicher, 2010; Araslı ve Tümer, 2008; Büte, 2011a; Karademir, 2016) ve örgütsel sessizlikle ilişkisi orta düzeyde bulunmuştur (Aydın, 2016).

\section{2. Örgütsel Muhalefet}

Örgütsel muhalefet, örgütsel politika ve uygulamalara ilişkin olarak üst yönetimle farklılaşmanın dile getirilmesi ve/veya aynı zamanda bu farklılaşmayı bir iletişim kanalı olarak kullanan bir geri bildirim faaliyetidir.

Muhalefet davranışı doğrudan ve dolaylı olarak örgütün demokratik yapısının gelişmesine yardımcı olabileceği gibi sorun kümesi içeren uygulamaların ve yönetsel tercihlerin sorgulanmasının da yolunu açacaktır.

Kavramın etimolojik kökeni ve vurguladığı olgusal yapısı, olumsuz bir karakter içerse de araştırmalar muhalefet davranışının örgütsel süreçler açısından kritik düzeyde düzeltici etkilere yönelik adımları da barındırdığı ifade edilmektedir.

Shahinpoor ve Matt (2007) de muhalefet davranışının karşılık bulduğu örgütlerin daha şeffaf ve hesap verebilir, çalışanların ise daha motive olduklarını ifade etmişlerdir. Çalışanlar yüksek motivasyonundan dolayı örgütlerine daha fazla katkı sağlamak isterler. Çalışanlar muhalefet ettikleri olay/durum karşısında seslilik stratejisi izlerken, örgüte dair güçlü bir sadakat duygusu da hakimdir (Shahinpoor ve Matt, 2007:38).

Hirschman Shahinpoor ve Matt'in seslilik ve sadakat yaklaşımını, muhalefet girişiminde iki davranış türü ile ilişkilendirerek desteklemiştir. Hirschman'a göre; örgütünde ki olay/durumdan memnun olmayan çalışan, iki davranış ihtimali ile yüzleşmek durumundadır. Bunlardan ilki, örgütten ayrılmaya yönelmek, diğeri ise, örgüttün gelişimi için konuşmaktır. Sadık çalışan örgütten ayrılma yerine konuşmayı seçecektir. Çalışanların örgütten ayrılması, 
muhalefeti ölümcül hale getirmektedir. Bu bağlamda muhalefet, örgütü mükemmel hale getirebilir ve problemlerin çözümünü sağlayabilir (Hirschman, 1994:272).

Farrell, örgütsel muhalefette sesliliği aktif ve yapıcı, örgütsel muhalefete bağlı ayrılma davranışını aktif ve yıkıcı, ihmal davranışını pasif ve yıkıcı, sadakat davranışını pasif ve biraz yıkıcı olarak bir davranış olarak ifade etmektedir. Farrell sadık davranışı, çıkış ya da muhalefet arasında bağımsız bir hareket olabileceğini belirtmiş̧tir (Farrell, 1983).

Dolayısıyla örgütler, örgütsel sorunların önüne geçebilmek ve çalışanların muhalefet etme davranışlarının önünü açabilmek amacıyla çeşitli uygulama ve politikalar uygulamaya sokmaktadırlar. Örgütün yapısı, kültürü, büyüklügü ve yapısı, kurumsal düzeyi, yöneticinin vizyonu, yönetici ile iletişim kanallarının varlığı, liderlik anlayışı ile iş yapma anlayışı, kişilik, tecrübe, kıdem süresi, çalışanın çalışma süresi, statüsü, performans ve rol tanımı gibi faktörler çalışanların muhalefet etmesini etkilemektedir.

Muhalefet süreci, çalışan ve yönetici arasında iletişim ya da fikir alışverişi imkânı yaratmaktadır. Çalışanlar, muhalif bir yaklaşımla örgüte dair yanlış giden ya da genel teşmil edilmeyecek durumlar hakkında geribildirimde bulunabilmekte ve çalş̧anların genel görüşlerini yöneticilere iletebilmektedir. Yapılan muhalefet sürecinde çalışanlar tarafından alınan kararların etkili olması ya da karar alınırken dikkate alınması beklenir.

Yönetici muhalefeti, örgütü ve çalş̧anları hakkında bir geribildirim süreci olarak anlamlandırabiliyorsa bunu aynı zamanda örgütü geliştirmek için bir firsat olarak da tahvil edecektir. Bu bakış açısı yöneticilere örgütte karşılaşılabilecek sorunlar daha erken müdahale imkânı verecektir.

Çalışanlar yönetimin karar uygulamalarına ilişkin bir olumsuz tepki ya da mevcut düzenin işleyişine karşı çıkma davranışı gösterebilirler (Biçkes, 2017). Bu bağlamda muhalefet davranışı, örgütlerin faaliyetlerinde çeşitli düzeylerde olumsuz davranışlar olabilir ve farklılıklar içerebilir. Kassing ve Armstrong (2002) örgütsel işleyişteki olumsuz davranışları örgütsel değişimi, karar alma biçimlerini, verimsizliği, görev ve sorumluluklardaki dengesiz dağılımı, adil olmayan kaynak dağılımını, adaletsiz performans değerlendirmeyi, etik dış1 uygulamaları ve örgütsel bazı uygulamaların taraflara zarar vermesini örgütlerde muhalefetin başlatıcıları olarak sıralamıştır (Acaray, 2018:85).

Temelde muhalefet eyleminde bulunanlar örgütteki sorunlara dikkat çekme, çalışanlara veya örgüte zarar gelmesini önleme gibi rasyonel nedenlerle hareket etmektedirler (Kassing ve Armstrong, 2002).

Kassing (1997), örgütsel muhalefetin birbirini tamamlayan 4 aşamadan oluştuğunu ifade etmiştir. Örgütsel muhalefetin ilk aşamasında çalışanı muhalif bir boyuta taşıyan tetikleyici faktör ortaya çıkar. İkinci aşamada çalışan muhalefet kararını etkileyen bireysel, ilişkisel ve örgütsel faktörler ile ifade tarzı seçimine odaklanmaktadır. Üçüncü aşamada çalışan karşı olmanın risklerini belirlemekte ve son aşamada muhalif düşüncesini diğerleri ile paylaşmaktadır.

Örgütsel muhalefeti ortaya çıkaran daha doğru bir ifade ile tetikleyen faktörler, adil olmayan ve etik dışı uygulamalar, kişisel çıkarlarının zedelenmesi, örgütsel kararların alınış biçimi, sonuçlandırılamayan örgütsel kararlar, görev ve sorumluluk dă̆glımları, örgütsel kaynakların kullanımı ve paylaşımı, performans değerlendirmelerdir (Kassing ve Armstrong, 2002). Tsai ve Hsiung ise (2013) personelin örgüt için algıladığı risk, örgütün gerileme beklentisi, 546 
psikolojik sözleşme ihlali ve çalışanlar arasında olumsuz olarak yapılan haksız karşılaştırma sonucu ortaya çıkan öfke duygusunu örgütsel muhalefeti tetikleyen unsurlar olarak işaret etmiştir.

Muhalefet davranışı içerisindeki çalışanlara yönelik olarak örgüt yöneticileri üç farklı türde davranış geliştirmektedir (Graham, 1986). Bu tepkisel davranışlardan ilki yöneticinin demokratik bir tutum içerisinde, muhalif örgüt üyelerinin davranışının desteklemesidir. Bir diğer yaklaşım ise, muhalifin davranışa olumlu ya da olumsuz tepki verilmemesidir. Yöneticilerin muhalif bir davranışa karşı geliştirebilecekleri bir diğer davranış türü ise, örgüt üyesinin cezalandırılmasıdır. Bu tür davranışta muhalif örgüt üyesi farklı düzeylerde cezai müeyyidelerle karşı karşıya kalabilmektedir.

Kassing, örgütsel muhalefeti dikey muhalefet, yatay muhalefet ve dışa aktarılmış muhalefet boyutlarından oluşan üç boyutlu bir yapı halinde ele almıştır. Dikey muhalefet, örgütte kendi konumunun üstünde bulunanlara doğrudan açıklanan açık ve doğrudan dile getirilmesi durumudur. Dikey muhalefet çalışanın sorunları ve sorunlara yönelik olarak çözüm önerilerini üstlerine anlaşılır ve açık ve yapıcı bir şekilde ifade etmesidir. Yatay muhalefet çalışanın yöneticilerine muhalefetini herhangi bir nedenle ifade edemediği durumlarda örgüt içindeki etkisiz kişilere ya da hayal kırıklığına uğramış çalışanlarına açıklamaları durumudur. Çalışan yatay muhalefet yoluyla sorun olarak gördüğü hususlar ile ilgili düşüncelerini, bu sorunların çözümüne doğrudan bir katkı sunabilecek kişiler yerine sorunun çözümüne etki edebilme gücü olmayanlara ya da aynı olumsuz durumdan mustarip olan diğerlerine daha eleştirel ve öfke merkezli bir dil ile ifade etmektedir. Yatay muhalefet daha çok çalışanın yönetim ile iletişim kuramadığı hallerde sirayet etmektedir. Dışa aktarılmış muhalefet ise, çalışanın tepkisini iş dışındaki arkadaşları, eşleri, aile üyeleri ya da yabancılar gibi örgüt dışında kimselere açıklamasıdır. Bu eğilimde olan çalışanlar karşılaştıkları sorunlar karşısında sessiz kalarak itiraz etmeme yoluna gitmektedirler.

\subsection{Kayırmacılık, Örgütsel Muhalefet Boyutları Arasındaki Etkileşimler}

Kayırmacılık ile örgütsel muhalefet davranışı arasındaki ilişki "sosyal mübadele kuramı" bağlamında değerlendirilmiştir. Sosyal mübadele kuramı, örgüt düzeyinde karşılıklı ilişkileri açıklamaya çalışan bir kuramdır.

Kayırmacılık, sorumlulukların paylaşımı, kaynakların dağıtılması gibi boyutlarda ilişkisel düzeyde gerçekleşmektedir. Dolayısıyla bir mübadele temelinde şekillenmektedir. Bireyler arası ve birey-örgüt arası sosyal ilişkiler sosyal mübadele kuramı çerçevesinde değerlendirilmektedir. Sosyal mübadele kuramı tarafların, bir beklenti içinde sosyal ilişkilere girmesi ve bu ilişkileri sürdürmesini açıklamaktadır. Kuramdaki "beklenti" ile ifade edilen, ihlal edildiğinde olumsuz sonuçlar doğuran karşılıklı zorunluluklardır. Bu bağlamda kurama göre örgütler, çalışanlar için doğru işler yaptıkları ve yaptıkları işlerin çalışanlar tarafından doğru algılamalarını sağladıkları müddetçe sosyal mübadele devam etmektedir (Turunç ve Çelik, 2010:185)

Örgütsel muhalefet örgütlerde yaşanan etik sıkıntılar, çalışanların tatminsizlikleri, yanlış giden uygulamalar vb. gibi konularda gelişim fırsatı veren ve örgüte önemli geri bildirimler sunan bir süreçtir.

Alanyazında kayırmacılık bir kişinin kendi akrabalarını örgüte, bir kamu kuruluşuna vb. yerlere yerleştirmesi, bir üst makama terfi ettirmesi, bazı ayrıcalıklardan istifade ettirmesi 
(lojman, yurt dışı görev vb.), ya da başka bir üst göreve tayin ettirmesi anlamlarını içermektedir (Bedük, 2010: 182). Kayırmacılık, politik taraftarlık, partizanlık, hemşericilik, aynı zümreye mensubiyet, etnisite, aynı okuldan mezun olmak gibi sebeplere bağlı olarak yapılmaktadır. Kayırmacılığın yaygınlaştığı, liyakatin göz ardı edildiği toplumlarda kamu imkânlarının, genellikle politik gücü elinde tutanlar, sermaye sahipleri, karizmatik liderler, eş-dost gibi kişi ve grupların lehine kullanılması, doğal olarak toplumsal hareketliliğin bir kesimin/grubun aleyhine işletilmesine neden olmaktadır.

Kayırmacılık örgüt içinde çalışanların sadakatinin azalmasına, örgüt içi ilişkilerin bozulmasına, koordinasyonun zayıflamasına, işe olan bağlılığın azalmasına, işe devamsızlık ve işgücü devir oranının artmasına neden olmaktadır (Araslı vd., 2006: 304). Buna mukabil kayırmacılık örgütler açısından verimsizliğe sebebiyet vermekte, çalışanın performansını negatif yönde etkilenebilmektedir.

Kassing, örgütsel muhalefet davranışını tetikleyen nedenleri farklı başlıklar altında değerlendirmiştir (Kassing, 2002). Kassing'in örgütsel muhalefeti tetikleyen unsurlar içerisinde görev, yetki ve sorumlulukların dağıtımı, kaynakların temini ve kullanımı ve performans değerlendirmeleri de bulunmaktadır. Kayırmacılığın sorumluluk dağıtımı, kaynakların paylaşılması, performansın dikkate alınmadan yetkilendirme gibi boyutlarda gerçekleşmesi kayırmacılık ile örgütsel muhalefet arasında bir etki arayabileceğimizi düşündürtmektedir.

Alanyazında kayırmacılık davranışlarının çalışanların adalet algılarında negatif bir durum ortaya çıkardığına dair tespitler yapılmıştır. Öte yandan kayırmacılık davranışlarıyla yüzleşen çalışanların örgütsel sessizlik, bağlılık, iş tatmini gibi tutum ve davranışları üzerindeki olumsuz etkiler ortaya çıkardığı, dolayısıyla benzer olumsuz etkilerin örgütsel muhalefet davranışı üzerinde görülmesi kuvvetle muhtemel olarak değerlendirilebilir.

Alanyazında bu iki değişken arasındaki etkileşimi inceleyen tek çalışma özelliğini taşıyan Özüren ve Paksoy’un (2018) çalışmasında muhalefet ile kayırmacılık arasında bütüncül olarak bir etkileşim tespit edilmemiştir. Ancak aynı araştırmada yatay muhalefet, işe alma kayırmacılığından etkilendiği, dikey muhalefetin ise kayırmacılıktan etkilenmediği tespit edilmiştir.

Kayırmacılık olgusunun ve boyutlarının çeşitli araştırmalarda örgütsel davranış alanyazındaki birçok değişkenle birlikte ele alındığı ve bu kavramlarla ilişkili olduğu görülmektedir. Kayırmacılığın türü ve boyutları her ne olursa olsun, örgütsel muhalefeti etkileyebilen bir faktör olarak değerlendirildiği için bu iki kavram birlikte ele alınarak, kavramlar arası ilişkinin siyaseten daha yoğun ilişkilerin yaşandığı bir örgütte çalışanların algılarına göre incelenmiş olması bu çalışmayı önemli kılmaktadır.

Kayırmacılığg ilişkisel düzeyde örgütsel muhalefeti etkileyebilen bir faktör olarak dikkate alırsak iki değişken arasındaki etki, sosyal mübadele kuramı bağlamında değerlendirilmiştir. $\mathrm{Bu}$ bağlamda sınırları çizilmiş kuramsal çerçeve ve alanyazında yapılmış çalışmaların sonuçlarından yola çıkarak araştırmanın temel hipotezi aşağıdaki gibi kurulmuştur:

H1: Kayırmacılık örgütsel muhalefet üzerinde pozitif ve anlamlı bir etkiye sahiptir. 


\section{ARAŞTIRMANIN YÖNTEMI}

$\mathrm{Bu}$ araştırma için geliştirilen modeli test etmek için sayısal verilere odaklanan nicel araştırma yöntemi kullanılmış ve verilerin toplanmasında anket tekniğinden faydalanılmıştır.

\subsection{Araştırmanın Amacı ve Modeli}

$\mathrm{Bu}$ araştırmada kayırmacılık algısının örgütsel muhalefet davranışı üzerinde oynadığı rolü tespit etmektir. Bu amaçla tasarlanan araştırma modeli Şekil 1'de gösterilmiştir.

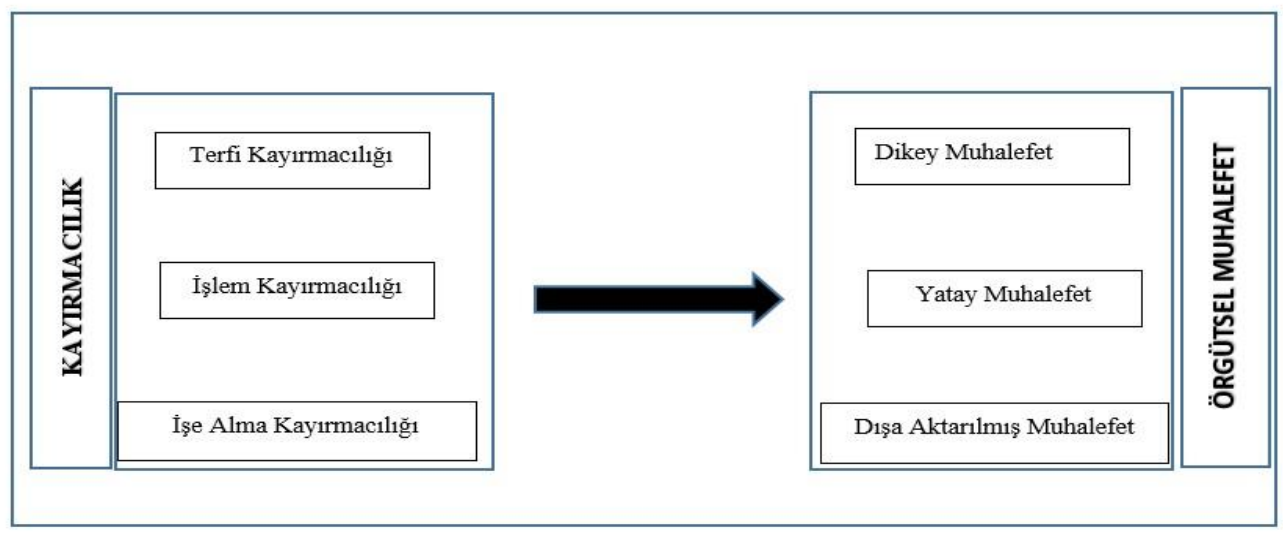

Şekil.1 Araştırma Modeli

\subsection{Araştırmanın Evreni ve Örneklemi}

Araştırmanın evrenini Isparta İl Özel İdare Genel Sekreterliğinde görev yapan çalışanlar oluşturmaktadır. İlgili örgütün çalışanlarının tümüne dijital ortamda gönderilen anket formlarından 198'i geri dönmüştür. Elde edilen anket formlarından hatalı ve eksik doldurduğu tespit edilen 17 adet form ve uç değer olarak belirlenen 8 adet form çıkarılmış, 173 anket değerlendirmeye alınmıştır.

Bryman ve Cramer (2005), tercih edilen ölçeklerdeki madde sayısının 5 katı deneğe ulaşılmasının, evreni temsil için yeterli olabileceğini ifade etmiştir. Dolayısıyla araştırmada kullanılan ölçeklerin toplamda 31 madde içermesi nedeniyle ulaşılan örneklem sayısının yeterli olduğu düşünülmektedir.

\subsection{Veri Toplama Tekniği ve Kullanılan Ölçekler}

$\mathrm{Bu}$ araştırmada anket yöntemi kullanılarak veriler elde edilmiştir. Verilerin toplanmasında kullanılan örgütsel muhalefet ölçeği Kassing (1998) tarafından geliştirilmiştir. Ergün ve Çelik (2018) tarafından Türkçe'ye uyarlaması yapılan üç boyutlu örgütsel muhalefet ölçeği, dikey muhalefet, yatay muhalefet ve dişa aktarılmış muhalefet boyutlarından teşkil etmiştir. Ölçek 17 adet kapalı uçlu soru ve beşli likert tipi ifadeden oluşmaktadır. Orijinal ölçeğin Cronbach alpha katsayıları dikey muhalefet için $(\alpha) .83$, yatay muhalefet için $\alpha=.82$ ve dişa aktarılmış muhalefet için $\alpha=.75$ olarak bulunmuştur. Bu bulgular, ölçeği oluşturan tüm alt boyutların iç tutarlığının yüksek olduğunu göstermektedir (Ergün, Çelik, 2018). Ölçekte olumsuz anlama sahip olan 2-3-4-6-8-10-14. maddeleri ise ters puanlanmıştır. 
Çalışanların kayırmacılığa ilişkin tutumlarını belirlemek için Ford ve McLaughin (1985) ve Abdalla ve diğerleri (1998) tarafından geliştirilen ve Asunakutlu ve Avcı (2009) tarafindan Türkçeye uyarlanan ölçek kullanılmıştır. Ölçek 14 adet kapalı uçlu soru ve beşli likert tipi ifadeden oluşmaktadır. Ölçeğin üç alt boyutu vardır ve bunlar terfide kayırmacılık, işlem kayırmacılığı ve işe alma sürecinde kayırmacılıktır. Asunakutlu ve Avcı tarafından yapılan çalışmada ölçeğin alt boyutlarına ilişsin güvenirlik değerleri terfide kayırmacılıkta 0,88 , işlem kayırmacılığında 0,83 ve işe alma sürecinde kayırmacılıkta 0,67 olarak bulunmuştur. Ölçekte ters puanlanan madde bulunmamaktadır.

\subsection{Araştırmada Kullanılan İstatistiksel Yöntemler}

Araştırma verilerinin analizinde SPSS 22 programı kullanılmıştır. Çalışmada ayrıca kullanılan ölçeklerin geçerliliğini test etmek için AMOS 22.0 istatistik programından yararlanılmıştır. Ölçeklerin geçerliliği doğrulayıcı faktör analizi yardımıyla sınanmıştır. Ölçeklerin güvenilirliğini ölçmek için ise iç tutarlılık katsayısı tercih edilmiştir. Araştırmada kullanılan değişkenlerin aralarındaki ilişkilerin ve etkilerin test edilmesinde korelasyon ve regresyon analizi kullanılmıştır.

\section{BULGULAR}

Araştırma kapsamında elde edilen bulgular, başlıklar halinde değerlendirilmiştir.

\subsection{Demografik Bulgular}

Katılımcılılara ait demografik nitelikler Tablo 1'de verilmektedir.

Tablo 1. Katılımcılara Yönelik Demografik Veriler

\begin{tabular}{|l|l|l|l|}
\hline & & Sayı & Yüzde \\
\hline Cinsiyet & Erkek & 139 & 80.3 \\
\hline & Kadın & 34 & 19.7 \\
\hline Ĕ̆itim & Lise & 77 & 44.50 \\
\hline & Önlisans & 10 & 5.8 \\
\hline & Lisans & 73 & 42.19 \\
\hline & Yüksek Lisans & 13 & 7,5 \\
\hline Kıdem Yılı & $1-5$ Yil & 31 & 17.9 \\
\hline & $6-10$ Yil & 48 & 27.7 \\
\hline & $11-15$ Yil & 27 & 15.6 \\
\hline & $16-20$ Yil & 25 & 14.5 \\
\hline & $21-25$ Yil & 14 & 8.1 \\
\hline & $26-30$ Yil & 24 & 13.9 \\
\hline & $30+$ Yil & 4 & 2.3 \\
\hline Medeni Durum & Evli & 141 & 81.5 \\
\hline & Bekâr & 32 & 18.5 \\
\hline Yaş & $18-25$ & 7 & 4.0 \\
\hline & $26-30$ & 39 & 22.5 \\
\hline & $31-40$ & 78 & 45.1 \\
\hline & $41-50$ & 38 & 22.0 \\
\hline & & & \\
\hline
\end{tabular}




\begin{tabular}{|l|l|l|l|}
\hline & $50+$ & 11 & 6.4 \\
\hline Toplam & & 173 & 100 \\
\hline
\end{tabular}

Katılımcıların cinsiyet dağılıma ağırlıklı olarak erkeklerden oluşmuştur. Yerel Yönetim hizmetleri alanındaki çalışma alanlarının niteliği gereği ağırlıklı olarak erkek çalışanlardan oluşması beklenen bir sonuçtur. Evli çalışanların oranı bekâr çalışanlara nazaran daha fazladır. Çalışanların eğitim seviyesi ağırlıklı olarak lise ve lisans seviyesindedir. Kıdem açısından çalışanlar değerlendirildiğinde ise çoğunluğunun 10 yıl üzerinde olduğu görülmüştür. Katılımcıların yaş dağılımlarının çoğunluğu 26 ile 50 arasında değişmektedir.

\section{2. Ölçeklerin Geçerlilik ve Güvenilirlik Analizleri}

Araştırmada kullanılan ölçeklerle elde edilen verilerin normal dağılım göstermesi, bağımlı bağımsız değişkenlerin doğrusal ilişki içinde olması, hata varsayımlarının homojen dağılım göstermesi gerekmektedir (Tabachnick ve Fidel, 2014:112). Araştırma verilerinin çarpıklık ve basıklık değerlerinin $+3,-3$ arasında olduğu tespit edilmiştir. Çarpıklık ve basıklık değerlerinin +3, -3 aralığında olması, dağılımın normalden aşarı sapma göstermediği anlamına gelebilir (Kline, 2011:62).

Kayırmacılık ve örgütsel adalet ölçeğinin yapı geçerliliğini ortaya koymak amacıyla, AMOS 22 istatistik paket programı ile birinci düzey doğrulayıcı faktör analizi (DFA) gerçekleştirilmiştir. Gerçekleştirilen analiz sonucunda elde edilen değerler, kabul edilebilir uyum değerler arasında olmadığından programın önerdiği modifikasyonlar yapılmıştır. Buna göre örgütsel kayırmacılık ölçeği için kovaryansı yüksek olan 3 değer arasında yeni kovaryanslar oluşturulmuş ve örgütsel muhalefet ölçeğin için kovaryansı yüksek olan 4 değer arasında yeni kovaryanslar oluşturulmuş. Modifikasyon sonrasında modele ait değerlerin kabul edilebilir sınırlar içerisinde olduğu görülmüştür (Tablo 2).

Tablo 2. Ölçeklerin Uyum Değerleri

\begin{tabular}{|c|c|c|c|c|c|c|}
\hline & $\mathbf{X}^{2}$ & df & $X^{2} / d f$ & GFI & CFI & RMSEA \\
\hline Örgütsel Kayırmacılık & 142.333 & 71 & 2.004 & 0,89 & 0.97 & 0.07 \\
\hline Örgütsel Muhalefet & 275.060 & 111 & 2.475 & 0.90 & 0.95 & 0.08 \\
\hline İyi Uyum Değerleri* & & & $\leq 3$ & $\geq 0.90$ & $\geq 0.97$ & $\leq 0.05$ \\
\hline $\begin{array}{l}\text { Kabul Edilebilir Uyum } \\
\text { Değerleri }\end{array}$ & & & $\leq 4-5$ & $\begin{array}{ll}\geq & 0.89- \\
0.85 & \end{array}$ & $\geq 0.95$ & $\leq 0.06-0.08$ \\
\hline & $\begin{array}{l}*(\mathrm{~N} \\
199\end{array}$ & & & $\begin{array}{l}\text { *Joreskog } \\
\text { 4) }\end{array}$ & Sör & 1993 \\
\hline
\end{tabular}

Ölçeklerin doğrulayıcı faktör analizi sonucunda elde edilen örgütsel kayırmacılık ölçeği $(\mathrm{X} 2 / \mathrm{df}=2.004 ; \mathrm{RMSEA}=0.07 ; \mathrm{CFI}=0.97 ; \mathrm{GFI}=0.89)$ ve örgütsel muhalefet $\left(\mathrm{X}^{2} / \mathrm{df}=2.475\right.$; $\mathrm{RMSEA}=0.08$; $\mathrm{CFI}=0.95$; GFI= 0.90), ölçeklerine ait uyum iyiliği değerleri ile iyi uyum değerleri arasında yer aldığından tüm ölçeklerin yapı geçerliliği sağlanmıştır.

Ayrıca ölçeklerin güvenilirliklerini ölçmek amacıyla iç tutarlılık katsayılarına bakılmıştır. Örgütsel kayırmacılık ölçeğinde 14 madde ve 3 boyut yer almaktadır. Ölçeğin Cronbach Alfa 
katsayısı 0.83'tür. Ölçeğin alt boyutlarına ilişkin Cronbach Alfa katsayıları terfide kayırmacılıkta 0.61 , işlem kayırmacılığında 0.75 ve işe alma kayırmacılığında 0.82 olarak bulunmuştur. Örgütsel muhalefet ölçeğinde 17 madde ve 3 boyut yer almaktadır. Ölçeğin Cronbach Alfa katsayısı $0.88^{\prime}$ dir. Ölçeğin alt boyutlarına ilişkin Cronbach Alfa katsayısı dikey muhalefette 0.84 , yatay muhalefette 0.65 ve dişa aktarılmış muhalefette 0.85 olarak bulunmuştur. Ölçeklerin içsel tutarlılık katsayıları, alanyazında kabul edilen değerin üzerinde olduğu tespit edilmiştir ( $\alpha \geq 60$ ). Elde edilen iç tutarlılık katsayısına göre, kullanılan ölçeklerin güvenilir düzeyde oldukları değerlendirilmiştir (Nunnally, 1978; Sipahi, Yurtkoru, Çinko, 2008:89).

\subsection{Değişkenler Arası İlişkilere İlişkin Bulgular}

Örgütsel kayırmacılık ve örgütsel muhalefete dair ilişkiler Pearson Korelasyon analizi yardımıyla analiz edilmiştir. Bu kapsamda hazırlanan Tablo 3'te ayrıca değişkenlere ait aritmetik ortalama, standart sapma ve varyans değerleri de verilmiştir.

Tablo 3. Ölçek Maddelerine Ait Tanımlayıcı İstatistikler

\begin{tabular}{|r|l|l|l|}
\hline & Ort. & S.s. & Varyans \\
\hline Örgütsel Muhalefet & 3.802 & .681 & .465 \\
\hline Dikey Muhalefet & 4.00 & .682 & .466 \\
\hline Yatay Muhalefet & 3.54 & .737 & .544 \\
\hline Dışa Aktarılmış Muhalefet & 3.87 & .806 & .650 \\
\hline Örgütsel Kayırmacılık & 3.680 & .399 & .160 \\
\hline Terfi Kayırmacıı̆̆ğ1 & 3.27 & .453 & .205 \\
\hline İşlem Kayırmacııı̆ı & 3.98 & .520 & .271 \\
\hline İşe Alma Kayırmacılığı & 3.77 & .911 & .830 \\
\hline
\end{tabular}

Ölçeklerin ortalaması 3 'ün üzerindedir. Çalışanların kayırmacılığa kıyasla örgütsel muhalefet algılarının ortalaması ise daha yüksektir. Örgütsel muhalefet ölçeği içerisinde dikey muhalefet boyutunun ortalaması ise 4.00 'dır. Dikey muhalefet, muhalif görüşlerin yöneticilere yönelik direk ve açık bir şekilde ifade edilmesini kapsamaktadır. Çalışanlarda dikey muhalefet eğiliminde olmaları oldukça anlamlıdır. Çünkü çalışanların iş garantisi kapsamında çalışıyor olmaları ve yerel siyasetin etkilerinin tezahür ettiği bir örgütte çalışmaları ile doğrudan ilişkili olabilir.

Tablo 4. Değişkenlere Ait Korelasyon Analizi

\begin{tabular}{|c|c|c|c|c|c|c|}
\hline & $\begin{array}{c}\text { Dikey } \\
\text { Muhalefet }\end{array}$ & $\begin{array}{c}\text { Yatay } \\
\text { Muhalefet }\end{array}$ & $\begin{array}{c}\text { Dişa } \\
\text { Aktarılmış } \\
\text { Muhalefet }\end{array}$ & $\begin{array}{c}\text { Terfi } \\
\text { Kayırmacılığ } 1\end{array}$ & $\begin{array}{c}\text { İşlem } \\
\text { Kayırmacılığ }\end{array}$ & $\begin{array}{c}\text { İşe Alma } \\
\text { Kayırmacı } \\
\operatorname{loğ} 1_{1}\end{array}$ \\
\hline Dikey Muhalefet & 1 & & & & & \\
\hline Yatay Muhalefet & $.763 * *$ & 1 & & & & \\
\hline $\begin{array}{l}\text { Dışa Aktarılmış } \\
\text { Muhalefet }\end{array}$ & $.836 * *$ & $.858 * *$ & 1 & & & \\
\hline $\begin{array}{l}\text { Terfi } \\
\text { Kayırmacılığ } 1\end{array}$ & -.012 & .005 & -.015 & 1 & & \\
\hline
\end{tabular}




\begin{tabular}{|c|c|c|c|c|c|c|}
\hline $\begin{array}{l}\text { İsslem } \\
\text { Kayırmacılığ }\end{array}$ & $.627 * *$ & $.566^{* *}$ & $.628 * *$ & .011 & 1 & \\
\hline $\begin{array}{l}\text { İşe Alma } \\
\text { Kayırmacılığ1 }\end{array}$ & $.773 * *$ & $.776 * *$ & $.881 * *$ & -.017 & $.613 * *$ & 1 \\
\hline
\end{tabular}

Tablo 5'de görüldüğü gibi en yüksek korelasyon değeri .88 ile işe alma kayırmacılığı ile dışa aktarılmış muhalefet arasında olduğu görülmektedir. İşlem kayırmacılığ 1 ile dikey muhalefet $(\mathrm{r}=.62 \mathrm{p}<.01)$, yatay muhalefet $(\mathrm{r}=.56 \mathrm{p}<.01)$ ve dişa aktarılmış muhalefet $(\mathrm{r}=.62 \mathrm{p}<.01)$ arasında orta düzeyde, pozitif ve anlamlı bir ilişki olduğu görülmektedir. İşe alma kayırmacılığı ile dikey muhalefet $(\mathrm{r}=.77 \mathrm{p}<.01)$, yatay muhalefet $(\mathrm{r}=.77 \mathrm{p}<.01)$ ve dışa aktarılmış muhalefet $(\mathrm{r}=.88 \mathrm{p}<.01)$ arasında yüksek düzeyde, pozitif ve anlamlı bir ilişki olduğu görülmektedir. Buna göre katılımcıların işlem ve işe alma kayırmacılığı algısı arttıkça dikey muhalefet, yatay muhalefet ve dışa aktarılmış muhalefete ilişkin algıları da artmaktadır.

\subsection{Hipotez Testine İlişkin Bulgular}

Tablo 5. Kayırmacılık Algısının Örgütsel Muhalefetin Dikey Muhalefet Boyutuna Yordama Düzeyi

\begin{tabular}{lllll}
$\mathrm{R}$ & $\mathrm{R}^{2}$ & Düzeltilmiş $\mathrm{R}^{2}$ & $\mathrm{Sd}$ & Durbin-Watson \\
\hline .761 & .580 & .572 & .446 & 2.13 \\
\hline
\end{tabular}

$p<.01, \mathrm{~F}=77.707, p=.000$

Tablo 5'de ki $\mathrm{R}^{2}$ değeri incelendiğinde katılımcıların kayırmacılığın terfi, işlem ve işe alma boyutlarına ilişkin algıları örgütsel muhalefetin dikey muhalefet boyutunun yaklaşık olarak \% 58'ini açıkladığı görülmektedir. Yani örgütsel muhalefetin dikey boyutundaki varyansın \%58' i kayırmacılığın terfi, işlem ve işe alma boyutları tarafından açıklandığı söylenebilir. Yapılan analiz sonuçlarına göre $\mathrm{F}_{(3-169)}=.77 .707, p=.00$ modelin istatistiksel olarak anlamlı olduğu ifade edilebilir.

Tablo 6. Kayırmacılık Algısının Örgütsel Muhalefet Davranışının Dikey Muhalefet Boyutunu Açıklama Düzeyi ile İlgili Regresyon Analizi Sonuçları

\begin{tabular}{lccccccc}
\hline & $\mathrm{B}$ & $\mathrm{Sd}$ & $\beta$ & $\mathrm{t}$ & $\mathrm{p}$ & Tolerans & $\mathrm{VIF}$ \\
\hline Terfi Kayırmacılı̆̆ & .06 & .07 & .04 & .80 & .42 & .99 & 1.00 \\
\hline İslem Kayırmacılığ 1 & .31 & .08 & .24 & 3.89 & .00 & .64 & 1.55 \\
\hline İse Alma Kayırmacılığ 1 & .44 & .04 & .59 & 9.55 & .00 & .64 & 1.54 \\
\hline$p<.05$ & & & & & & &
\end{tabular}

Tablo 6'ya göre kayırmacılığın işlem ve işe alma boyutlarının örgütsel muhalefetin dikey muhalefet boyutu üzerinde anlamlı yordayıcı değişkenler olduğu, ancak terfi kayırmacılığının, örgütsel muhalefet boyutları üzerinde anlamlı yordayıcı değişken olmadığı söylenebilir. En önemli yordayıcının işe alma kayırmacılığı boyutu, daha sonra ise işlem kayırmacılığı boyutuna ilişkin algıların oluşturduğu saptanmıştır. Kayırmacılığın işe alma kayırmacılık boyutuna ilişkin algıların örgütsel muhalefetin dikey boyutuna pozitif yönde anlamlı olarak yordadığı ifade edilebilir $\beta=.59 ; t=9.55 ; p<.05)$. Kayırmacılığın işlem 
kayırmacılığı boyutuna ilişkin algılarının örgütsel muhalefetin dikey boyutunu pozitif yönde anlamlı olarak yordamaktadır $(\beta=.24 ; t=3.89 ; p<.05)$. Diğer bir ifade ile katılımcıların kayırmacılığın işe alma kayırmacılık boyutuna ilişkin algılarında bir birimlik artışın örgütsel muhalefetin dikey muhalefet boyutuna ilişkin algılarını .44 birim arttıracağı ve kayırmacılığın işlem kayırmacılığı boyutuna ilişkin algılarında bir birimlik artışın, örgütsel muhalefetin dikey muhalefet boyutuna ilişkin algılarının .31 birim arttıracağı belirlenmiştir. $\mathrm{Bu}$ bulgulara göre katılımcıların işe alma ve işlem kayırmacılığına yönelik algıları arttıkça örgütsel muhalefetin dikey muhalefet boyutuna yönelik algılarının da artacağı söylenebilir.

Tablo 7. Kayırmacılık Algısının Örgütsel Muhalefetin Yatay Muhalefet Boyutunu Yordama Düzeyi

\begin{tabular}{lllll}
$\mathrm{R}$ & $\mathrm{R}^{2}$ & Düzeltilmiş $\mathrm{R}^{2}$ & $\mathrm{Sd}$ & Durbin-Watson \\
\hline .716 & .513 & .504 & .519 & 1.90 \\
\hline
\end{tabular}

$p<.01, \mathrm{~F}=59.327, p=.000$

Tablo 7'de $\mathrm{R}^{2}$ değerine göre katılımcıların kayırmacılığın terfi, işlem ve işe alma boyutlarına ilişkin algıları örgütsel muhalefetin yatay muhalefet boyutunun yaklaşık olarak \% 51 'ini açıkladığı görülmektedir. Yani örgütsel muhalefetin yatay muhalefet boyutundaki varyansın \% 51' i kayırmacılığın terfi, işlem ve işe alma boyutları tarafından açıklandığı söylenebilir. Yapılan analiz sonuçlarına göre $\mathrm{F}_{(3-169)}=59.327, p=.00$ modelin istatistiksel olarak anlamlı olduğu söylenebilir.

Tablo 8. Kayırmacılık Algısının Örgütsel Muhalefet Davranışının Yatay Muhalefet Boyutunu Açıklama Düzeyi ile İlgili Regresyon Analizi Sonuçları

\begin{tabular}{lccccccc}
\hline & $\mathrm{B}$ & $\mathrm{Sd}$ & $\beta$ & $\mathrm{t}$ & $\mathrm{p}$ & Tolerans & $\mathrm{VIF}$ \\
\hline Terfi Kayırmacılı̆̆ & .11 & .08 & .06 & 1.26 & .20 & .99 & 1.00 \\
\hline İşlem Kayırmacilı̆̆ & .13 & .09 & .09 & 1.44 & .15 & .64 & 1.55 \\
\hline İşe Alma Kayırmacılı̆̆ & .52 & .05 & .65 & 9.77 & .00 & .64 & 1.54 \\
\hline
\end{tabular}

$p<.05$

Tablo 8 incelendiğinde kayırmacılığın işe alma boyutunun örgütsel muhalefetin yatay muhalefet boyutu üzerinde anlamlı yordayıcı değişken olduğu, ancak terfi ve işlem kayırmacılığının anlamlı yordayıcı değişkenler olmadığı söylenebilir. Kayırmacılığın işe alma kayırmacılık boyutuna ilişkin algıların örgütsel muhalefetin yatay muhalefet boyutuna pozitif yönde anlamlı olarak yordadı̆̆ı söylenebilir $\beta=.65 ; t=9.77 ; p<.05$ ). Katılımcıların kayırmacılığın işe alma kayırmacılık boyutuna ilişkin algılarında bir birimlik artma olduğunda örgütsel muhalefetin yatay muhalefet boyutuna ilişkin algılarının .52 birim artacağı belirlenmiştir. Bu bulgulara göre katılımcıların işe alma kayırmacılığına yönelik algıları arttıkça örgütsel muhalefetin yatay muhalefet boyutuna yönelik algılarının da artacağı söylenebilir. 
Tablo 9. Kayırmacılık Algısının Örgütsel Muhalefetin Dışa Aktarım Muhalefet Boyutunu Yordama Düzeyi

\begin{tabular}{lclll}
\hline $\mathrm{R}$ & $\mathrm{R}^{2}$ & Düzeltilmiş $\mathrm{R}^{2}$ & $\mathrm{Sd}$ & Durbin-Watson \\
\hline .869 & .756 & .751 & .402 & 2.02 \\
\hline$p<.01, \mathrm{~F}=174.331, p=.000$ & & &
\end{tabular}

Tablo 9'da $\mathrm{R}^{2}$ değeri incelendiğinde katılımcıların kayırmacılığın terfi, işlem ve işe alma boyutlarına ilişkin algıları örgütsel muhalefetin dışa aktarım muhalefeti boyutunun yaklaşık olarak \% 75'ini açıkladığı görülmektedir. Yani örgütsel muhalefetin dışa aktarım muhalefeti boyutundaki varyansın $\% 75$ 'i kayırmacılığın terfi, işlem ve işe alma boyutları tarafindan açıklandığı söylenebilir. Yapılan analiz sonuçlarına göre $\mathrm{F}_{(3-169)}=.174 .331, p=.00$ modelin istatistiksel olarak anlamlı olduğu söylenebilir.

Tablo 10. Kayırmacılık Algısının Örgütsel Muhalefet Davranışının Dışa Aktarılmış Muhalefet Boyutunu Açıklama Düzeyi ile İlgili Regresyon Analizi Sonuçları

\begin{tabular}{lccccccc}
\hline & $\mathrm{B}$ & $\mathrm{Sd}$ & $\beta$ & $\mathrm{t}$ & $\mathrm{p}$ & Tolerans & $\mathrm{VIF}$ \\
\hline Terfi Kayırmacılı̆̆ & .02 & .06 & .01 & .41 & .67 & .99 & 1.00 \\
\hline İşlem Kayırmacılığı & .19 & .07 & .12 & 2.61 & .01 & .64 & 1.55 \\
\hline İşe Alma Kayırmacılığ 1 & .70 & .04 & .79 & 16.71 & .00 & .64 & 1.54 \\
\hline$p<.05$ & & & & & &
\end{tabular}

Tablo 10'a göre kayırmacılığın işlem ve işe alma boyutlarının örgütsel muhalefetin dışa aktarılmış muhalefet boyutu üzerinde anlamlı yordayıcı değişkenler olduğu, ancak terfi kayırmacılığının anlamlı yordayıcı değişken olmadığı söylenebilir. En önemli yordayıcının işe alma kayırmacılığı boyutuna ilişkin algıları, daha sonra ise işlem kayırmacılığı boyutuna ilişkin algıların oluşturduğu saptanmıştır. Kayırmacılığın işe alma kayırmacılık boyutuna ilişkin algıların örgütsel muhalefetin dışa aktarım boyutuna pozitif yönde anlamlı olarak yordadığ 1 ifade edilebilir $\beta=.79 ; t=16.71 ; p<.05)$. Kayırmacılığın işlem boyutuna ilişkin algıların örgütsel muhalefetin dışa aktarılmış muhalefet boyutunu pozitif yönde anlamlı olarak yordadığı söylenebilir $(\beta=.12 ; t=2.61 ; p<.05)$. Katılımcıların kayırmacılığın işe alma boyutuna ilişkin algılarında bir birimlik artma olduğunda örgütsel muhalefetin dışa aktarılmış muhalefet boyutuna ilişkin algılarının. 70 birim artacağı ve kayırmacılığın işlem boyutuna ilişkin algılarında bir birimlik artma olduğunda örgütsel muhalefetin dışa aktarılmış muhalefet boyutuna ilişkin algılarının .19 birim artacağı belirlenmiştir. Bu bulgulara göre katılımcıların işe alma ve işlem kayırmacılığına yönelik algıları arttıkça örgütsel muhalefetin dışa aktarılmış muhalefet boyutuna yönelik algılarının da artacağı söylenebilir. 


\section{SONUÇ ve TARTIŞMA}

$\mathrm{Bu}$ çalışmanın amacı, bir kamu yerel yönetim örgütünde görev yapan çalışanların, kayırmacılık algılarının örgütsel muhalefet davranışını ne düzeyde etkilediğini belirlemektir.

Kayırmacılığın alt boyutlarından, işlem kayırmacılığı algısının örgütsel muhalefetin dikey muhalefet, yatay muhalefet ve dışa aktarılmış muhalefet boyutları ile orta düzeyde pozitif ve anlamlı, işe alma kayırmacılığı algısının örgütsel muhalefetin dikey muhalefet, yatay muhalefet ve dışa aktarılmış muhalefet boyutları ile yüksek düzeyde pozitif ve anlamlı bir ilişkisi olduğu anlaşılmıştır. Kayırmacılığın terfi kayırmacılığı boyutunun örgütsel muhalefet ve boyutları arasında anlamlı bir ilişki tespit edilememiştir. Bu bağlamda katılımcıların işlem ve işe alma kayırmacılığı algısı arttıkça dikey muhalefet, yatay muhalefet ve dışa aktarılmış muhalefetine ilişkin algıları da artmaktadır.

Katılımcıların kayırmacılığın terfi, işlem ve işe alma boyutlarına ilişkin algıları örgütsel muhalefetin dikey muhalefet boyutunun yaklaşık olarak \% 58'ini, dişa aktarılmış muhalefet boyutunun yaklaşık olarak \% 75'ini, yatay muhalefet boyutunun yaklaşık olarak \% 51'ini açıkladı̆̆ı görülmektedir.

Kayırmacılığın işlem ve işe alma boyutlarının, örgütsel muhalefetin dikey muhalefet boyutu üzerinde anlamlı yordayıcı değişkenler olduğu, katılımcıların işe alma kayırmacılığına yönelik algıları arttıkça örgütsel muhalefetin yatay muhalefet boyutuna yönelik algılarının artacağı ifade edilebilir. Öte yandan katılımcıların işe alma ve işlem kayırmacılığına yönelik algıları arttıkça örgütsel muhalefetin dikey muhalefet ve dışa aktarılmış muhalefet boyutuna yönelik algılarının da anlamlı bir şekilde artacağı söylenebilir.

Kayırmacılık ile yeteneksiz kişilerin işe alınması, bazı çalışanlara taraflı davranılması, liyakate dayanmayan terfilerin olması diğer çalışanlar üzerinde olumsuz etkiler ortaya çıkarmaktadır. Kayırmacılık neticesi çalışanlar sorunlarını ve sorunlarına yönelik çözüm önerilerini dikey olarak muhalefet dürtüsü ile yöneticilerine iletmeyi tercih etmektedirler. Dolayısıyla örgütlerde temel insan kaynakları fonksiyonları olan personel seçme, işe yerleştirme ve terfi gibi uygulamaların yerine kayırmacılığın öncelenmesi çalışanlar düzeyinde muhalefeti tetiklemektedir.

Alanyazında Kayırmacılık ve Örgütsel Muhalefet arasında yapılmış tek çalışma olan Özüren ve Paksoy (2019) tarafından gerçekleştirilen araştırmada kayırmacılık ile örgütsel muhalefet arasında bütüncül olarak bir etkileşim tespit edilememiştir. Ancak bahse konu olan araştırmada örgütsel muhalefetin yatay muhalefet boyutunun kayırmacılığın işe alma kayırmacılığı boyutundan etkilendiği tespit edilmiştir.

Araştırmamızda elde edilen sonuçların Özüren ve Paksoy’un (2019) işe alma kayırmacılığı ile yatay muhalefet arasındaki bulguları ile örtüştügü̈, Toytok ve Uçar'ın (2018) tarafindan yapılan araştırma sonuçlarıyla uyumlu olduğu tespit edilmiştir. Araştırma neticesinde, kayırmacılığın çalışanlarda örgütsel muhalefet algısına olumlu düzeyde etkisinin ortaya konulmasının, alanyazına önemli bir katkı sağladığı değerlendirilmektedir.

Yerli ve uluslararası alanyazında Özüren ve Paksoy’un (2019) çalışmasının dışında kayırmacılık ile örgütsel muhalefet ilişkisini dikkate alan bir çalışmaya rastlanmamıştır. Daha çok örgütlerde kayırmacılık ile ilgili iş tatmini (Araslı ve diğerleri, 2006; Büte, 2011); örgütsel bağlılık (Düz, 2012); iş performansı (İyiişleroğlu, 2006), örgüt hakkında olumsuz söz 
söyleme ve işten ayrılma niyeti (Mattila ve Patterson, 2004; Büte, 2011) arasında ilişkiler tespit edilmeye çalışılmıştır.

Ponzo ve Scoppa (2010) yürüttükleri bir araştırmada eğitim seviyesi düşük kişilerin kayırmacı uygulamalara başvurmaya daha eğilimli olduğu, yüksek mesai ücreti ödeyen şirketlerde kayırmacılığın daha yaygın olduğu ve firmaların işe alımlarda yetenek ve eğitimi daha az ön planda tuttuğunu tespit etmişlerdir. Bian, Huang ve Zhang (2015) iş arayanların güvenli iş imkânları edinmede hem zayıf hem de güçlü sosyal bağlarını kullandığı, bu ilişkilerin atamalarda yetenek, eğitim seviyesi ve tecrübe gibi özelliklerden daha etkili olduğu bulgulamıştır. Pounder ve Blase (1988) Fransa'da yürüttükleri araştırmada öğretmenlerin işe alma, terfi, atama, işten çıkarılma ve değerlendirme gibi uygulamalarda kayırmacılığa maruz kaldıklarını, ayrıca yöneticinin kurum içerisinde birçok unsur üzerinde kontrol mekanizmasının olduğunu belirtmişledir. Öğretmenlerin bu durumdan olumsuz etkilendiği ve çalıştıkları kuruma yabancılaştıkları sonucunu elde etmişlerdir. Kayırmacılığın örgütlerde çalışanların adalet algılarını bozucu, performanslarını düşürücü, örgüte bağlılıklarını sorgulatacak düzeyde etkileri olduğu çeşitli çalışmalarda ortaya konmuştur (Akar, 2020; Karahan, Yılmaz, 2014; Okçu ve Uçar, 2016). Chen (2008), yaptığ1 araştırmada kayırmacılığın örgütte çatışma ve stresin temel nedeni olduğunu tespit etmiştir.

Araştırmada elde ettiğimiz kayırmacılık algısının muhalefet davranışına kaynaklık edeceğine dair güçlü verilerin, uygulayıcılar tarafindan örgütsel düzeyde dikkatle izlenmesi gerektiğini açığa çıkartmıştır. Araştırma sonuçları özellikle politika yapıcılara, insan kaynakları yönetimi alanında, personel istihdam politikalarında ve terfiye yönelik uygulamalarda kayırmacılığın sonuçları açısından yönelik önemli mesajlar barındırmaktadır.

Örgütlerin objektif kriterlere göre personel istihdamı gerçekleştirmeleri, iş değerleme, ücret ve ödül yönetimi ile ilgili İK politikaları belirlemeleri, çalışanların niteliklerinin geliştirilmesi ve liyakate dayalı terfi süreçlerinin geliştirilmesi ve istisnai uygulamalardan uzak durulması örgütsel muhalefet davranışının ortaya çıkmasını engelleyecektir. Örgütler çalışanların bilgi beceri ve deneyimlerinin arttırılmasına yönelik eğitim politikaları belirlemeli, nitelik açısından personel terfilerinin geliştirilmesine imkân tanımalıdır.

Araştırmada bazı kısıtlar da söz konusudur. Bunlardan ilki, bu çalışmanın sadece kamu sektöründen ve sınırlı sayıda çalışanla ve politik ilişkilerin son derece dinamik bir seyir izlediği bir örgütte araştırmanın yapılmış olmasıdır. Bir diğer kısıt ise, araştırma sonuçlarının genelleştirilebilmesi için, farklı sektörlerden farklı örneklemler üzerinde araştırmanın tekrarlanmasında fayda görülmektedir.

Alanyazında gerçekleştirilen çalışmalarda kayırmacılığın birçok örgütsel davranışı olumsuz yönde etkilediği, çalışanlar üzerinde olumsuz etkiler bıraktığı gözlenmektedir. Dolayısıyla kayırmacılık muhalefet ilişkisini dikkate alan çalışmalara ihtiyaç gözükmektedir.

\section{KAYNAKÇA}

AKÖZER, M. (2003). “Kamuoyu Gözüyle Kamuda Yolsuzluk”. Görüş Dergisi, Aralık, 1422.

ARASLI, H., BAVİK, A. ve EKİZ, E. (2006). The Effects Of Nepotism On Human Resource Management: The Case Of Three, Four And Five Star Hotels In Northern Cyprus. International Journal Of Sociology And Social Policy. 26 (7/8), 295-308. 
AKAR, S. (2020). “Örgüt Kültüründe Bir İş Ahlakı Olarak Nepotizm,” Uluslararası Yönetim Akademi Dergisi, C.3, S.1, 241-251.

ASUNAKUTLU, T. ve AVCI, U. (2010). "Aile İşletmelerinde Nepotizm Algısı ve İş Tatmini ilişkisi Üzerine Bir Araştırma ". Süleyman Demirel Üniversitesi İIBF Dergisi, Cilt.15, No.2, 93-109.

AKTAN, C. C. (2001). Siyasal Ahlak ve Siyasal Yozlaşma. Yolsuzlukla Mücadele Stratejileri. (Edt: C. C. Aktan). Ankara: Hak-İş Yayınları.

AYDOĞAN, İ. (2009). "Favoritism in the Turkish Educational System: Nepotism, Cronyism and Patronage”. Educational Policy Analysis and Strategic Research, 4(1), 19-35.

ACARAY, A. (2018). "Örgütsel Muhalefet Üzerine Pozitif Psikolojik Sermayenin Etkisi: Eğitim Sektöründe Bir Çalışma”, Anemon Muş Alparslan Üniversitesi Sosyal Bilimler Dergisi,83-81.

BIAN Y., HUANG X. ve ZHANG L. (2015). Information and Favoritism: The Network Effect on Wage İncome in China. Social Networks, 40, 129-138.

BÜTE, M. (2011). "Kayırmacılığın Çalışanlar Üzerine Etkileri ile İnsan Kaynakları Uygulamaları İlişkisi: Türk Kamu Bankalarına Yönelik Bir Araştırma”. Atatürk Üniversitesi Sosyal Bilimler Enstitüsü Dergisi. 15 (1), 383-404.

BRYMAN, A. ve CRAMER, D. (2005). Quantitative Data Analysis with SPSS 12 and 13: A Guide for Social Scientists. New York: Routledge. Taylor \& Francis Group

BIERMAN, L. ve FISHER, C. D. (1984). “Antinepotism Rules Applied to Spouses: Business and Legal Viewpoints”. Labor Law Journal, October, 634-642.

BİÇKES, D. M. (2017). "Konaklama İşletmelerinde Örgütsel Muhalefetin Bireylerarası Saldırganlık Üzerindeki Etkisi: Kapadokya'daki Otellerde Bir Araştırma”. Atatürk Üniversitesi İktisadi ve İdari Bilimler Dergisi, 31(4).

BÜTE, M. (2011). "Kayırmacılığın Çalışanlar Üzerine Etkileri ile İnsan Kaynakları Uygulamaları İlişkisi: Türk Kamu Bankalarına Yönelik Bir Araştırma”. Atatürk Üniversitesi Sosyal Bilimler Enstitüsü Dergisi, 15(1), 383-404.

CHEN, Z. (2008). Collusion and Strategic Favoritism in Organizations. ESRC Centre for Competition Policy Working Paper, 08(27), 1-21. Cheney.

ÇARIKÇI, İ. H. ve ARSLAN, E. T. (2010). Türk Yönetim Geleneğinde Kayırmacılığın Tarihi Seyri. R. Erdem (Ed.). Yönetim ve Örgüt Açısından Kayırmacılık, 27-39. İstanbul: Beta Yayıncılık.

DÜZ, S. (2012). "Konaklama İşletmelerinde Nepotizm ile Örgütsel Bağlılık Arasındaki İlişkinin İncelenmesi”. (Yüksek Lisans Tezi). Afyon Kocatepe Üniversitesi, Sosyal Bilimler Enstitüsü.

FORD, R. ve MCLAUGHIN, F. (1985). “Nepotism”, Personnel Journal, September, 64, 7-61.

ERDEM, M. ve MERİÇ, E. (2012). “Okul Yönetiminde Kayırmacılığa İlişkin Ölçek Geliştirme Çalışması”. Eğitim Bilimleri Araştırmaları Dergisi, 2(2), 141-154. 
FARRELL, D. (1983). "Exit, Voice, Loyalty and Neglect as Responsesto Job Dissatisfaction: A Multidimensional Scaling Study”. Academy of Management Journal, 26 (4), 596607.

GRAHAM, J. W. (1986). "Principled Organizational Dissent. A Teoratical Essay”, Research in Organizational Behavior, 8, 1-52.

HAMILTON, D. K. (2010). "Patronage in Illinois: The Political Subjugation of Public Administration". Review of Public Personnel Administration, 30(2), 137-165.

HIRSCHMAN, A. O. (1994). Excerpt from Chapter Eight Exit, Voice and Loyalty: Responses to Decline in Firms, Organizations and States. The Social Contract, 4 (4), 272-275.

İLHAN, S. ve AYTAÇ, Ö. (2010). Yönetim ve Örgüt Açısından Kayırmacılık. Ramazan Erdem (Ed.), Türkiye'de Kayırmacı Eğilimlerin Oluşmasında Toplumsal ve Kültürel Yapının Rolü İçinde (61-83). İstanbul: Beta.

IYYİŞLEROĞLU, S. C. (2006). Aile Şirketleri: Adana ve Çevresinde Faaliyet Gösteren Aile Şirketlerinde Nepotizm Uygulamasının Tespitine Yönelik Bir Araştırma, Yayınlanmamış Yüksek Lisans Tezi, Adana.

KASSING, J. W. (1998). Development and Validation of the Organizational Dissent Scale. Management Communication Quarterly, 12(2), 183-229.

KASSING, J. W. ve ARMSTRONG, T. A. (2002). "Someone's Going to Hear About This: Examining the Association Between Dissent-Triggering Events and Employees' Dissent Expression”, Management Communication Quarterly, 16 (1): 39-65.

KAYABAŞI, Y. (2005). "Politik Yozlaşmaya Çözüm Olarak Anayasal İktisat (Yüksek Lisans tezi). https://tez.yok.gov.tr/UlusalTezMerkezi.

KARACAOĞLU, K. ve YÖRÜK, D. (2012). "Çalışanların Nepotizm ve Örgütsel Adalet Algılamaları: Orta Anadolu Bölgesinde Bir Aile İşletmesi Uygulaması.” İş, Güç, Endüstri İlişkileri ve İnsan Kaynakları Dergisi, 14(3), 43-64.

KARAHAN, A. ve YILMAZ, H., (2014). "Nepotizm Ve Örgütsel Bağlılık Arasındaki İlişkinin İncelenmesi ve Bir Uygulama", Selçuk Üniversitesi İktisadi ve İdari Bilimler Fakültesi Sosyal ve Ekonomik Araştırmalar Dergisi, Y11, 14, S. 27.

KURT, E. ve DOĞRAMACI, B., (2014). "Terfi, İşlem Kayırmacılığı ve İşe Alma Boyutlarında Kayırmacılık Davranışı Algısının Ölçülmesi: İstanbul İlinde Faaliyet Gösteren Bir Belediye İştirakinde Çalışanlar Üzerine Bir Araştırma”, Elektronik Mesleki Gelişism ve Araştırma Dergisi, C.2.

MATTILA, A. S. ve PATTERSON, P. G. (2004). The İmpact of Culture on Consumers' Perceptions of Service Recovery Efforts. Journal of Retailing, 80(3), 196-206

SHAHINPOOR, N. ve MATT, B. F. (2007). The Power of One: Dissent and Organizational Life. Journal of Business Ethics, 74(1), 37-48.

SIPAHİ, B., YURTKORU, E.S. ve ÇİNKO, M. (2008). Sosyal Bilimlerde SPSS ile Veri Analizi. İstanbul: Beta. 
ŞİMŞEK, M. Ş., ÖĞE, H. S. (2007). Stratejik ve Uluslararası Boyutları ile İnsan Kaynakları Yönetimi, Ankara, Gazi Kitabevi.

TSAI, N. T. ve HSIUNG, H. H. (2013). “A Force-Field Perspective on Dissent Behavior: The Interaction Between Employee Negative Perception and Group Positive Climate". Northeast Decision Sciences Institute Annual Meeting Proceedings, New York.

TURUNÇ, Ö. ve ÇELİK M. (2010). "Çalışanların Algıladıkları Örgütsel Destek ve İş Stresinin Örgütsel Özdeşleşme ve İş Performansına Etkisi”, Yönetim ve Ekonomi, 17(2),183-206.

TOYTOK, E. H. ve UÇAR, A. (2018). "The Effect of Administrators' Behaviors That Involves Favoritism on Organizational Opposition, " Journal of Education and Training Studies Vol. 6.

TÜRK DİL KURUMU (1998). Türkçe Sözlük. Ankara: Türk Dil Kurumu Yayınları.

OKÇU, V. ve UÇAR, A. (2016). Effect Of School Principals' Favouritism Behaviors And Attitudes On Teachers' Organizational Commitment, Based On The Perceptions Of Primary And Secondary School Teachers. Journal of HumanSciences, 13(3).

ÖZÜREN, Ü. ve PAKSOY, M. (2019). “İşgörenlerin Nepotizm Algılarının Örgütsel Muhalefet Tutumları Üzerindeki Etkisi: İstanbul'da Çorap Sanayi Çalışanları Üzerinde Bir Araştırma", Selçuk Ün. Sos. Bil. Ens.; (41): 210-219.

ÖZSEMERCİ, K. (2003). "Türk Kamu Yönetiminde Yolsuzluklar, Nedenleri, Zararları ve Çözüm Önerileri”. Ankara Sayıştay Araştırma Dizisi.

PONZO, M. ve SCOPPA, V. (2010). The Use of İnformal Networks in Italy: Efficiency or Favoritism?. The Journal of Socio-Economics, 39(1), 89-99.

POUNDER, D. G. ve BLASE, J. J. (1988). Principal Favoritism: Explanations, Effects, and Implications for Practice. Planning and Changing, 19(1), 3-7.

YILDIRIM, M. (2013). “Kamu Yönetiminin Kadim Paradoksu: Nepotizm ve Meritokrasi”. Celal Bayar Üniversitesi Sosyal Bilimler Dergisi, 11(2). 